This article is licensed under the Creative Commons Attribution-NonCommercial 4.0 International License (CC BY-NC) (http://www.karger.com/Services/OpenAccessLicense). Usage and distribution for commercial purposes requires written permission.

\title{
Multiple Fixed Drug Eruption Mimicking Parapsoriasis en Plaque in a Patient with Hepatitis C Virus Infection
}

\author{
Michie Katsuta $^{a} \quad$ Akihiko Asahina $^{a}$ Tetsuo Shiohara $^{\mathrm{b}}$ \\ aDepartment of Dermatology, The Jikei University School of Medicine, Tokyo, Japan; \\ ${ }^{b}$ Department of Dermatology, Kyorin University School of Medicine, Tokyo, Japan
}

\section{Keywords}

Hepatitis C virus - Lymphocyte transformation test - Multiple fixed drug eruption .

Parapsoriasis en plaque $\cdot$ Pegylated interferon $\alpha-2 b$ plus ribavirin

\begin{abstract}
Although hepatitis $\mathrm{C}$ virus ( $\mathrm{HCV}$ ) infection is often associated with extrahepatic cutaneous manifestations such as lichen planus, it is unclear whether HCV per se or HCV-specific immune responses play a pathophysiological role in the development of HCV-related cutaneous diseases. We recently treated a patient who developed parapsoriasis en plaque-like lesions after ingestion of various drugs. She showed hypersensitivity to multiple drugs after interferon therapy. Her clinical course was complicated by flares of parapsoriasis-like lesions which returned at precisely the same sites. The flares had begun within hours of ingesting nicardipine hydrochloride, amlodipine besilate, candesartan cilexetil and atenolol for the first time despite showing a low level of HCV RNA. Interestingly, the flares gradually subsided during continued treatment with these drugs while her HCV RNA level paradoxically increased: thus, there was an inverse correlation between flares and HCV RNA level. The eruptions were eventually
\end{abstract}

The Jikei University School of Medicine

3-25-8 Nishishimbashi, Minato-ku, Tokyo 105-8461 (Japan)

E-Mail mkatta@jikei.ac.jp 
diagnosed as fixed drug eruption, although the clinical manifestations mimicked parapsoriasis en plaque. Our results suggest that multiple drug hypersensitivity could be induced by antiviral immune responses that are cross-reactive to multiple drugs, but not by HCV per se.

\section{Introduction}

Although it has been reported that hepatitis $\mathrm{C}$ virus (HCV) can be pathogenic for several skin diseases [1-3], it is unclear whether HCV per se or hepatitis treatment agents cause these diseases. Although recently developed interferon (IFN)-free therapies for HCV shorten the treatment duration and alleviate sustained virologic responses [4], pegylated IFN (PEG-IFN) concomitant with ribavirin is used in patients with HCV genotype $1 \mathrm{~b}[5,6]$, and, as IFN is known to affect the cytokine cascade [7, 8], adverse effects of treatment with IFN plus ribavirin are attributed to IFN. Accordingly, since IFN can stimulate macrophages to produce IL-15, which activate anti-viral CD8 and natural killer cell responses [9], we hypothesized that adverse events in patients treated with these agents were IFN-induced immune responses not effects of HCV per se. If adverse events in HCV-infected patients were sustained HCV-specific immune responses, development or exacerbation of such events should be temporarily associated with decreased HCV viral load.

We report serial measures of HCV viral load and incidence of comorbid dermal lesions in a patient with chronic $\mathrm{HCV}$ infection.

\section{Case Report}

A 64-year-old woman presented to our Dermatology Department in April 2011 with a 2year history of progressive erythematous scaling eruption which first arose on her breasts as asymptomatic erythematous macules and patches and gradually spread to her neck, trunk, abdomen, and thighs. Her medical history included a blood transfusion in 1970 and a positive anti-HCV test by ELISA (enzyme-linked immunosorbent assay) in 2007. She had a history of hypertension and over several years had been sequentially treated with nicardipine hydrochloride, amlodipine besilate, and candesartan cilexetil. Because her blood pressure control was poor, her medication was changed three times in recent years (Fig. 1). Treatment with the latter was the only medication she reported and it was discontinued 2 months prior to presentation. She reported no personal or family history of autoimmune disease or drug eruptions. In January 2009, she had been started on combination therapy of PEG-IFN $\alpha$-2b plus ribavirin administered subcutaneously to treat progressive liver disease, but treatment was discontinued 2 months later, in March 2009, due to a persistently elevated serum level of alanine aminotransferase (ALT), despite a reduction in HCV RNA level. Three months later, in June 2009, she noticed macules on her breasts, but she could not rule out the possibility that the eruptions had developed prior to the administration of therapy.

Physical examination at the time of presentation revealed widespread reddish-gray macules of varying sizes with fine scales that were occasionally erythematous but never elevated. 
These macules were located on her neck, trunk, abdomen (Fig. 2), bilateral antecubital fossa, and posterior legs. Over most of her body, these macular processes were confluent. Histopathologic examination of a biopsy specimen from erythematous macules on the breast demonstrated a superficial, perivascular lymphocytic infiltrate with a vacuolar interface change, exocytosis and pigment incontinence in the papillary dermis, compatible with parapsoriasis en plaque.

Laboratory results at her initial presentation included: leukocyte count $5,400 / \mathrm{mm}^{3}$ (nor-

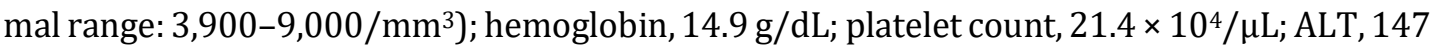
$\mathrm{IU} / \mathrm{mL}$; aspartate aminotransferase, $63 \mathrm{IU} / \mathrm{mL}$; rheumatoid factor and antinuclear antibody test findings were negative. She showed negative results in IgM anti-HAV antibody, IgM anti$\mathrm{HBc}$ antibody, HAV antigen and HBsAg antigen tests, but positive results in anti-HCV antibody tests. She has HCV genotype $1 \mathrm{~b}$, which is more common in Japan and Southeast Asia, and causes more severe hepatitis and higher levels of viremia. Findings from a liver biopsy showed moderate chronic active hepatitis. Quantitation of serum HCV RNA was determined by polymerase chain reaction, and serum HCV RNA level was $7.4 \times 10^{2} \mathrm{Eq} / \mathrm{mL}$. Four weeks of treatment by topical application of corticosteroids did not ameliorate the skin lesions. Meanwhile, following PEG-IFN $\alpha$-2b plus ribavirin therapy, her ALT level decreased but remained above normal, whereas discontinuation of PEG-IFN $\alpha-2 b$ plus ribavirin resulted in an increase in the HCV RNA level. Because the patient refused further PEG-IFN- $\alpha-2 b$ plus ribavirin therapy complaining of fatigue and headache, she stopped taking all medications except ursodeoxycholic acid, $900 \mathrm{mg}$ daily. Gradual improvement in skin lesions was noted over the next 2 months, but her skin lesions were not completely resolved by June 2011 .

Due to the possibility that her skin lesions had been a reaction to candesartan cilexetil, she was asked to avoid this medicine, and amlodipine besilate was re-administered to control her hypertension. However, a few days later on amlodipine besilate, her skin lesions worsened again (Fig. 3a), so amlodipine besilate was discontinued. By 8 weeks later, in August 2011, the skin lesions had disappeared. During those 8 weeks, she received no treatment for hypertension. Since her blood pressure was high $(165 / 110)$, the patient consented to start oral atenolol daily. Thereafter, the patient's course was complicated by additional recurrences of erythematous macules in precisely the same sites on the breasts, approximately a few days after she had begun taking atenolol. Three or 4 oval lesions appeared at previously involved sites on the breasts, but some previous sites on the neck and posterior legs showed no sign of recurrence. During several flare-ups of erythematous macules, HCV RNA and ALT levels fluctuated considerably. However, as the recurrences that appeared within a month of starting treatment with atenolol gradually subsided, HCV RNA levels increased. Thus, there was a clear inverse correlation between recurrence of the plaques and HCV RNA levels.

A few days before the start of taking atenolol, she consented to retake amlodipine besilate. Within $24 \mathrm{~h}$, a small oval erythematous plaque had reappeared at the previously affected site on the breasts (Fig. 3b). The recurrent lesion resolved within 3 days without any pigmentary change. Lymphocyte transformation tests with several drugs were performed on a number of occasions, and the results are summarized in Table 1 . Instances of recurrence were noted frequently over the next 3 years, during which time HCV RNA levels remained low. All skin lesions healed completely, while serum HCV RNA levels dramatically increased. Atenolol was continued after HCV RNA levels increased, but her blood pressure control was poor, so candesartan cilexetil was added again in June 2012. Oral challenge tests of atenolol were 
performed with no observed recurrences in January 2013. The patient was followed up for another year, during which time she remained free of eruptions.

\section{Discussion}

Previous studies evaluating the role of HCV in the development of drug eruptions have not included serial measurements of HCV RNA assessed in relation to the clinical course of the disease. However, fixed drug eruption (FDE) may be useful for assessing HCV viral loads, because the process of the evolution of individual lesions can be assessed. Our longitudinal evaluation of HCV RNA levels in sera from this patient demonstrated a close inverse correlation between HCV viral load in sera obtained at multiple time points and the presence of clinical symptoms of FDE: low levels of HCV RNA were temporarily associated with clinical symptoms of the disease. If these factors are associated, one might expect that patients with chronic HCV infection who show FDE may have low-titer HCV RNA. Although flare-ups of these lesions might be considered virally mediated, they may represent an HCV-specific immune response. In support of this possibility, positive lymphocyte transformation test reactions were only observed during periods when HCV RNA levels were relatively low. Due to the development of FDE 3 months after PEG-IFN $\alpha$-2b therapy, IFN would represent a triggering factor that can stimulate otherwise latent antiviral immune responses. A report of multiple FDE triggered by IFN + ribavirin in a patient with HCV infection supports this argument [10]. However, the immunopathologic mechanisms of these forms of antiviral immune responses might not require continued presence of a target virus. Indeed, one study reported "nonspecific" trapping of activated virus-specific T cells within inflamed sites [11]. This may explain why HCV RNA was not detected in lichen planus lesions from patients with chronic hepatitis C [12]. In our case, the eruptions were eventually diagnosed as FDE despite lack of common clinical features of hyperpigmentation. Guin and Baker [13] reported a case of chronic FDE caused by acetaminophen that simulated parapsoriasis en plaque. Interestingly, the lesions recurred at the same sites following administration of chemically unrelated medications, a finding referred to as polysensitivity [14]. Immune reactions to more than two chemically distinct drugs are referred to as polysensitivity [15], and polysensitivity in FDE lesions had been previously reported [14]. Since mycoplasms or viral infection can increase the risk of multiple drug hypersensitivity [15], polysensitivity in this case was more likely attributed to virus-specific CD8 ${ }^{+}$ $\mathrm{T}$ cells with cross-reactive potential that can be reactivated upon exposure to drugs.

\section{Conclusion}

This report is the only known attempt to correlate HCV viral load with the occurrence of FDE lesions using time-dependent analysis of HCV-RNA levels. We observed a strong inverse correlation between the development of FDE and HCV viral load, suggesting that HCV-specific immune responses may be involved in the pathogenesis of HCV-associated skin diseases. 


\section{Case Reports in Dermatology}

\section{Statement of Ethics}

The patient provided written informed consent. The study adhered to the tenets of the Declaration of Helsinki.

\section{Disclosure Statement}

The authors have no conflicts of interest to declare.

\section{Funding Sources}

No funding was obtained.

\section{Author Contributions}

Dr. Tetsuo Siohara wrote the initial draft of the manuscript and interpretation of data. Dr. Akihiko Asahina assisted in the preparation of the manuscript. All authors approved the final version of the manuscript, and agree to be accountable for all aspects of the work in ensuring that questions related to the accuracy or integrity of any part of the work are appropriately investigated and resolved.

\section{References}

1 Pawlotsky JM, Dhumeaux D, Bagot M. Hepatitis C virus in dermatology. A review. Arch Dermatol. 1995 Oct;131(10):1185-93.

2 De Vita S, Sacco C, Sansonno D, Gloghini A, Dammacco F, Crovatto M, et al. Characterization of overt B-cell lymphomas in patients with hepatitis C virus infection. Blood. 1997 Jul;90(2):776-82.

3 Ferri C, La Civita L, Monti M, Longombardo G, Greco F, Pasero G, et al. Can type C hepatitis infection be complicated by malignant lymphoma? Lancet. 1995 Nov;346(8987):1426-7.

4 Reddy KR, Bourlière M, Sulkowski M, Omata M, Zeuzem S, Feld JJ, et al. Ledipasvir and sofosbuvir in patients with genotype 1 hepatitis $C$ virus infection and compensated cirrhosis: an integrated safety and efficacy analysis. Hepatology. 2015 Jul;62(1):79-86.

5 Kohli A, Shaffer A, Sherman A, Kottilil S. Treatment of hepatitis C: a systematic review. JAMA. 2014 Aug;312(6):631-40.

6 Tanabe Y, Sakamoto N, Enomoto N, Kurosaki M, Ueda E, Maekawa S, et al. Synergistic inhibition of intracellular hepatitis $C$ virus replication by combination of ribavirin and interferon- $\alpha$. J Infect Dis. 2004 Apr;189(7):1129-39.

7 Gutterman JU. Cytokine therapeutics: lessons from interferon alpha. Proc Natl Acad Sci USA. 1994 Feb;91(4):1198-205.

8 Tilg H. New insights into the mechanisms of interferon alfa: an immunoregulatory and anti-inflammatory cytokine. Gastroenterology. 1997 Mar;112(3):1017-21.

9 Ma A, Boone DL, Lodolce JP. The pleiotropic functions of interleukin 15: not so interleukin 2-like after all. J Exp Med. 2000 Mar;191(5):753-6.

10 Sidhu-Malik NK, Kaplan AL. Multiple fixed drug eruption with interferon/ribavirin combination therapy for hepatitis C virus infection. J Drugs Dermatol. 2003 Oct;2(5):570-3. 


\section{Case Reports in Dermatology}

\begin{tabular}{l|l} 
Case Rep Dermatol 2020;12:25-32 \\
\hline DOI: 10.1159/000505477 & $\begin{array}{l}\text { (c) 2020 The Author(s). Published by S. Karger AG, Basel } \\
\text { www.karger.com/cde }\end{array}$ \\
\hline
\end{tabular}

Katsuta et al.: Multiple Fixed Drug Eruption Mimicking Parapsoriasis en Plaque in a Patient with Hepatitis C Virus Infection

11 Scotet E, Peyrat MA, Saulquin X, Retiere C, Couedel C, Davodeau F, et al. Frequent enrichment for CD8 T cells reactive against common herpes viruses in chronic inflammatory lesions: towards a reassessment of the physiopathological significance of $\mathrm{T}$ cell clonal expansions found in autoimmune inflammatory processes. Eur J Immunol. 1999 Mar;29(3):973-85.

12 Harden D, Skelton H, Smith KJ. Lichen planus associated with hepatitis C virus: no viral transcripts are found in the lichen planus, and effective therapy for hepatitis $\mathrm{C}$ virus does not clear lichen planus. J Am Acad Dermatol. 2003 Nov;49(5):847-52.

13 Guin JD, Baker GF. Chronic fixed drug eruption caused by acetaminophen. Cutis. 1988 Feb;41(2):106-8.

14 Shiohara T, Kokaji T. Polysensitivity in fixed drug eruption. J Am Acad Dermatol. 1997 Dec;37(6):1017-8.

15 Aoyama Y, Sawada F, Makino E, Shiohara T. Multiple drug sensitization syndrome: A distinct phenotype associated with unrecognized Mycoplasma pneumonia infection. JAAD Case Rep. 2017 Jul;3(4):301-5.

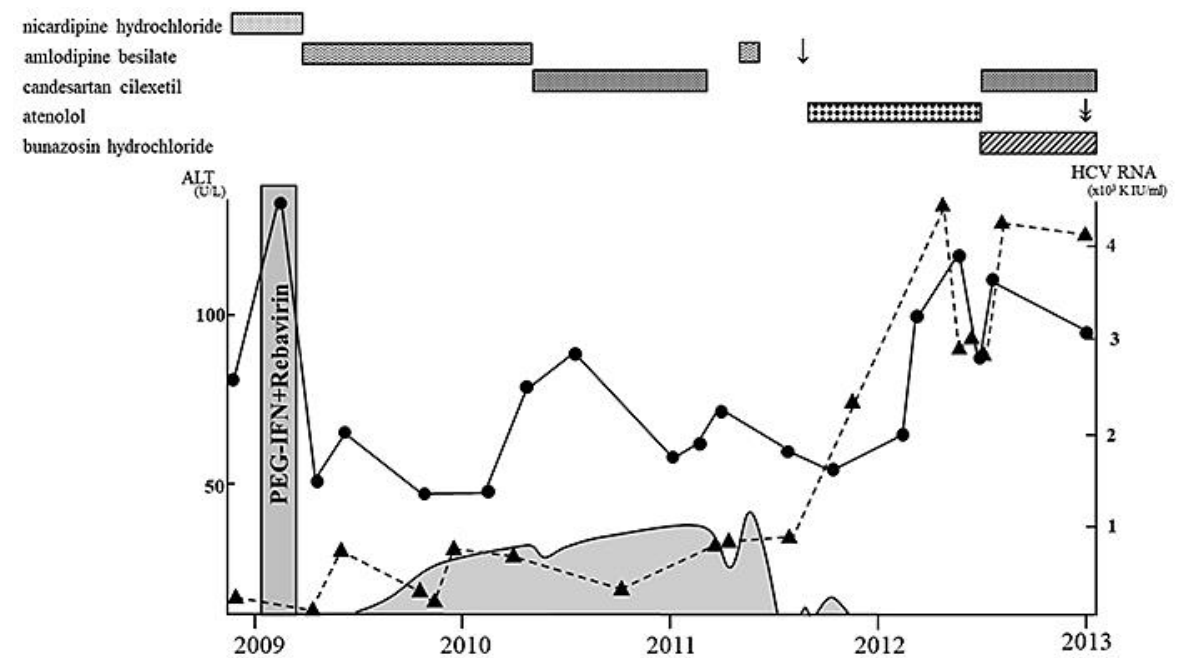

Fig. 1. Clinical course of drug-induced flare-ups in a patient with HCV infection, and the relationship between ALT and serum levels of HCV RNA. The shaded areas represent severity of eruptions. $\bullet$, ALT; $\boldsymbol{\Delta}$, HCV RNA; $\downarrow$, oral challenge test with amlodipine besilate; $\downarrow$, oral challenge test with atenolol. 


\section{Case Reports in Dermatology}

www.karger.com/cde

Katsuta et al:: Multiple Fixed Drug Eruption Mimicking Parapsoriasis en Plaque in a Patient with Hepatitis C Virus Infection
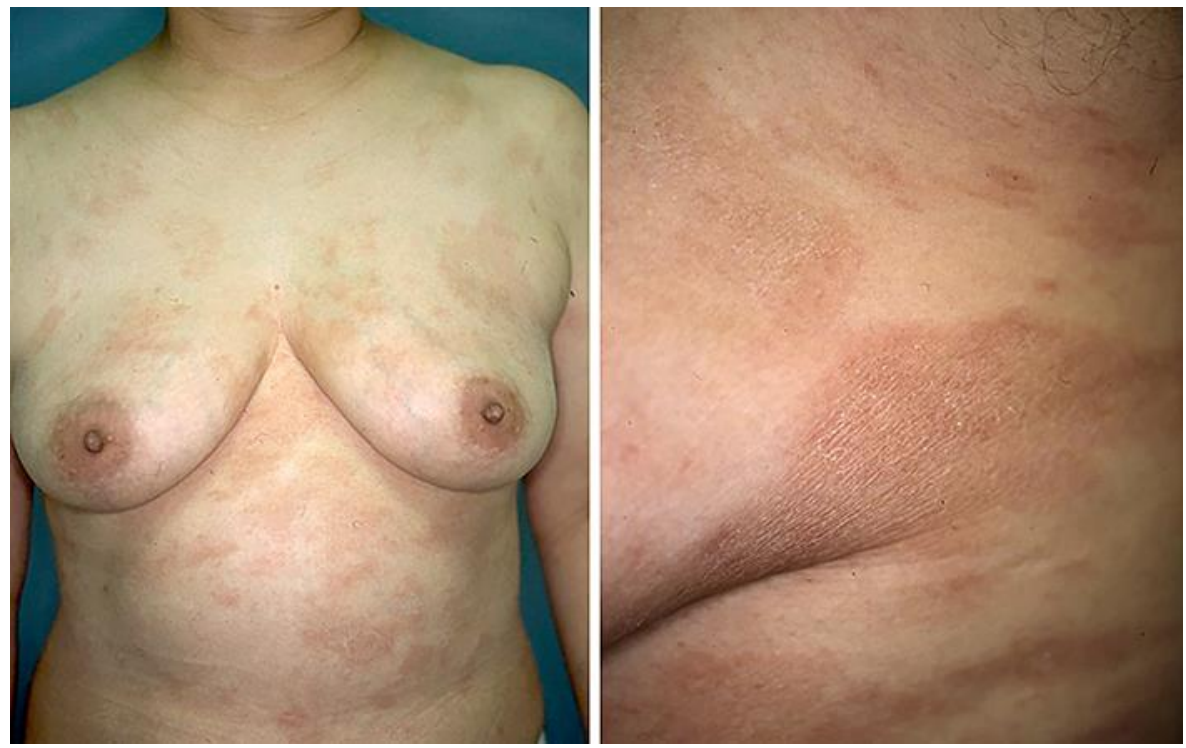

Fig. 2. Erythema on the neck and trunk resembling parapsoriasis.
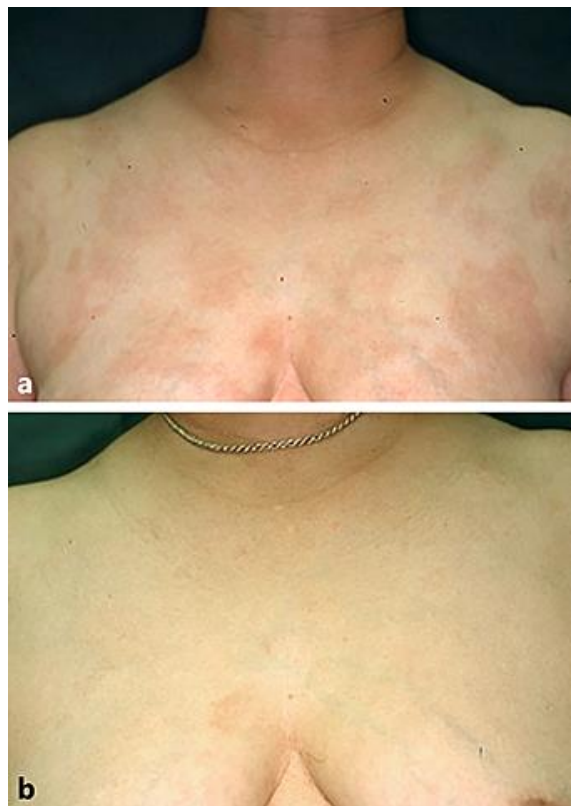

Fig. 3. a Taking amlodipine besilate in May 2011. b Erythematous plaque reappearance at the previously affected site after clinical challenge with amlodipine besilate. 


\section{Case Reports in Dermatology}

\begin{tabular}{l|l} 
Case Rep Dermatol 2020;12:25-32 \\
\hline DOI: 10.1159/000505477 & $\begin{array}{l}\text { (c) 2020 The Author(s). Published by S. Karger AG, Basel } \\
\text { www.karger.com/cde }\end{array}$ \\
\hline
\end{tabular}

Katsuta et al.: Multiple Fixed Drug Eruption Mimicking Parapsoriasis en Plaque in a

Patient with Hepatitis C Virus Infection

Table 1. Results of lymphocyte transformation tests with several drugs

\begin{tabular}{|c|c|c|c|c|c|c|}
\hline & \multicolumn{6}{|c|}{ Stimulation index (positive $>1.8$ ) } \\
\hline & \multicolumn{3}{|c|}{2011} & \multicolumn{2}{|l|}{2012} & \multirow{2}{*}{$\frac{2013}{\text { Jan. }}$} \\
\hline & Jul. & Aug. & Oct. & Jan. & Sep. & \\
\hline Amlodipine besilate & 1.63 & 2.79 & NT & NT & NT & NT \\
\hline Candesartan cilexetil & NT & NT & NT & NT & 1.34 & 1.59 \\
\hline Atenolol & 1.00 & NT & 3.25 & 1.26 & 1.73 & 1.91 \\
\hline Bunazosin hydrochloride & NT & NT & NT & 1.60 & NT & NT \\
\hline
\end{tabular}

NT, not tested; $\square$ All skin lesions disappeared. 